\title{
c-Myc protein is stabilized by fibroblast growth factor 2 and destabilized by ACTH to control cell cycle in mouse Y1 adrenocortical cells
}

\author{
Ana Paula Lepique, Miriam S Moraes, Kátia M Rocha, Claudia B Eichler, \\ Glaucia N M Hajj, Telma T Schwindt and Hugo A Armelin \\ Departamento de Bioquímica, Instituto de Química, Universidade de São Paulo, Av Prof. Lineu Prestes de Oliveira, 748, sala 924, São Paulo-SP, \\ 05508-900, Brasil
}

(Requests for offprints should be addressed to Hugo A Armelin; Email: haarmeli @quim.iq.usp.br)

\begin{abstract}
$\mathrm{ACTH}$ is the hormone known to control adrenal cortex function and maintenance in the intact animal but, in culture, it inhibits proliferation of adrenocortical cells from different mammalian species, a puzzle that has remained unsolved for nearly 30 years. In this paper we compare ACTH and fibroblast growth factor 2 (FGF2) antagonistic effects on the cell cycle in the Y1 cell line, a functional lineage of mouse adrenocortical tumor cells. This cell line displays chronic high levels of c-Ki-Ras-GTP, high active constitutive levels of phosphatidylinositol 3-OH kinase/Protein Kinase B (PI3K/AKT) and low constitutive basal expression of c-Myc, which accounts for a minor deregulation of the cell cycle. In $G_{0} / G_{1}$-arrested $Y 1$ cells, over-expression of the dominant negative mutant HaRasN17 drastically reduces c-Ki-Ras-GTP levels, eliminating basal c-Myc expression and basal $S$ phase entry. PI3K/Akt seems to be the downstream pathway from c-Ki-ras for deregulation of c-Myc basal expression, since wortmannin abolishes c-Myc expression in serum-starved, $G_{0} / G_{1}$-arrested $Y 1$ cells. FGF2 is a strong mitogen for $Y 1$ cells, promoting - in a manner dependent on the MEK/ERK pathway - c-myc transcription induction, c-Myc protein stabilization and $S$ phase entry in $G_{0} / G_{1}$-arrested $Y 1$ cells. On the other hand, ACTH causes c-Myc protein destabilization, partially blocking $S$ phase entry induced by FGF2, by a process dependent on the cAMP/protein kinase A (PKA) pathway. The whole pathway activated by ACTH to destabilize c-Myc protein in $\mathrm{Y} 1$ cells might comprise the following steps: $\mathrm{ACTH}$ receptor $\rightarrow$ CAMP/PKA $\rightarrow$ Akt deactivation $\rightarrow$ GSK3 activity liberation $\rightarrow$ c-Myc Thr58 phosphorylation.

We demonstrate that c-Myc regulation is a central key in the cell cycle control by these factors, since enforced expression of c-Myc through the MycER chimera abrogates the ACTH inhibitory effect over FGF2-induced S phase entry.
\end{abstract}

Journal of Molecular Endocrinology (2004) 33, 623-638

\section{Introduction}

We have been focusing on characterizing antagonistic mitogenic and anti-mitogenic signals initiated at, respectively, fibroblast growth factor 2 (FGF2) and adrenocorticotropin (ACTH) receptors in the mouse Y1 adrenocortical tumor cell line (Lotfi et al. 2000), aiming, in the long run, to elucidate the signaling circuitry that controls cell cycle and growth in adrenocortical cells. Here, we demonstrate that the antagonistic effect of ACTH towards FGF2 mitogenic activity narrows down to regulation of the c-Myc oncoprotein stability.
$\mathrm{Y} 1$ is an ACTH responsive, steroid secreting, clonal cell line (Yasumura et al. 1966, Schimmer 1981) that expresses high levels of ACTH receptors. Although the malignant phenotype of $\mathrm{Y} 1$ cells includes evasion from apoptosis and a limitless replicative potential, this cell line retains control mechanisms of the $G_{0} \rightarrow G_{1} \rightarrow S$ transition of the cell cycle, being highly responsive to mitogenic stimulation by FGF2 (Armelin et al. 1996, Lotfi et al. 1997, Lotfi \& Armelin 2001).

In $\mathrm{G}_{0} / \mathrm{G}_{1}$ cell cycle-arrested $\mathrm{Y} 1$ adrenocortical cells, FGF2 treatment elicits a strong mitogenic response that includes: (a) rapid and transient 
activation of ERK-MAPK (extra cellular signalregulated kinases-mitogen activated protein kinases) (2 to $10 \mathrm{~min}$ ); (b) transcriptional activation of c-fos, c-jun and c-myc genes (10 to $30 \mathrm{~min}$ ); (c) induction of cFos and cMyc proteins by $1 \mathrm{~h}$ and cyclin Dl protein by 5-6 h; and (d) onset of DNA synthesis initiation by 8-9 h (Armelin et al. 1996, Lotfi et al. 1997, Lotfi \& Armelin 2001, Rocha et al. 2003, Schwindt et al. 2003). ACTH, to some extent, resembles FGF2 by inducing transcription of c-fos, fosB and junB genes (Kimura et al. 1993, Lotfi et al. 1997, 2000, Lotfi \& Armelin 2001, Rocha et al. 2003). But, in spite of this resemblance to FGF2, ACTH is a strong antagonist of FGF2 mitogenic activity, inhibiting the cell cycle of $\mathrm{Yl}$ cells by blocking $\mathrm{G}_{1}$ progression (Armelin et al. 1977, Weidman \& Gill 1977, Kimura \& Armelin 1988, data provided in this paper). Thus, the interaction of ACTH and FGF2 is a complex phenomenon whose underlying molecular mechanisms should be central to growth regulatory pathways governing the $G_{0} / G_{1} \rightarrow S$ transition of the cell cycle.

In a preliminary communication, we presented data showing that FGF2 stabilizes the c-Myc protein whereas ACTH antagonizes FGF2, destabilizing c-Myc (Lepique et al. 2000). Here, we report that c-Ki-ras gene amplification, a genetic lesion found in Y1 cells (Schwab et al. 1983), causes a permanent minor deregulation of c-myc gene expression, via the phosphatidylinositol $3-\mathrm{OH}$ kinase (PI3K) pathway, without change in stability of both c-myc mRNA and c-Myc protein. FGF2 induces c-myc gene transcription and stabilizes the c-Myc protein by an ERK1/2-mediated process. ACTH, on the other hand, has the opposite effect, strongly destabilizing the $\mathrm{c}-\mathrm{Myc}$ protein via the $\mathrm{cAMP} /$ protein kinase A (PKA) pathway, without interfering with c-myc mRNA stability. In addition, we also observed that ACTH does not interfere with the late induction of the cyclin D1 protein.

To demonstrate that down-regulation of c-Myc protein level is a direct cause of ACTH antimitogenic activity, we devised a functional assay taking advantage of the gene construction, MycER chimera. MycER encodes a fusion-protein comprised by the entire $\mathrm{c}-\mathrm{Myc}$ and the estrogen receptor (ER)-binding domain, whose dissociation from cytoplasmic complexes and migration to the cell nucleus is inducible by 4' hydroxy tamoxifen (4'OH-tamoxifen) (Littlewood et al. 1995). Thus, we transfected MycER into Y1 cells to show that sustained expression and 4'OH-tamoxifen activation of MycER renders $\mathrm{Y} 1$ cells resistant to the negative effect of ACTH over FGF2 mitogenic stimulation.

\section{Materials and methods}

\section{Cell lines}

Gells from the mouse Y1 adrenocortical tumor cell line (Yasumura et al. 1966) and Y1-transfectant clonal lines carrying, respectively, dominant negative mutant genes ras N17 or PKA-R1, were grown in $10 \%$ fetal calf serum-Dulbecco's modified Eagle's medium (FCS-DME) minus or plus $100 \mu \mathrm{g} / \mathrm{ml} \mathrm{G418.} \mathrm{To} \mathrm{arrest} \mathrm{the} \mathrm{cell} \mathrm{cycle} \mathrm{at} \mathrm{the}$ $\mathrm{G}_{0} / \mathrm{G}_{1}$ boundary, exponentially growing cells in $10 \%$ FCS-DME were incubated for $48 \mathrm{~h}$ in serum-free medium (SFM). In SFM, Y1 cells are viable and fully responsive to both FGF2 and ACTH.

\section{Plasmids}

pBabe puromicin and pMycER (Littlewood et al. 1995) were gifts from Robert N Eisenman, Fred Hutchinson Cancer Research Center, Seattle, WA, USA, and $\mathrm{p} \Delta \mathrm{MycER}-$ Babe puromicin was from Linda Penn, Hospital Princess Margaret, Toronto, Canada; pcBZ054, containing the entire $1.3 \mathrm{kbp}$ of mouse cyclin Dl was a gift from CJ Sherr, Howard Hughes Medical Institute, Saint Jude Children's Research Hospital, Memphis, TN, USA. Plasmid pMMrasDN is a construct containing the rasN17 under the control of the MMTV promoter (Feig \& Cooper 1988, Cai et al. 1990) donated by L Feig (Tufts University, Boston, MA, USA). Plasmid pG324D, an expression vector carrying a mutated form of the PKA-regulatory subunit-1 (R1) gene under the control of the metallothionein promoter (Olson et al. 1993) was a gift from B Schimmer, University of Toronto, Canada.

\section{Antibodies, ACTH, FGF2, reagents and drugs}

Specific rabbit polyclonal antibodies against mouse c-Myc, cyclin D1, c-Fos and human estrogen receptor (ER) were purchased from Santa Cruz Biotechnology, Santa Cruz, CA, USA; mouse monoclonal anti-BrdU antibody was from 
Amersham Pharmacia; anti-mouse IgG-FITG (fluorescein isothiocyanate)-conjugated antibody was from Sigma; Vectastain Elite ABC kit was from Vector Laboratories, Inc., Burlingame, CA, USA. ECL Western Blotting-Enhanced Chemiluminescence kit was from Amersham Pharmacia. Synthetic ACTH peptide was synthesized and chemically characterized by HPLC, mass spectrometry and N-terminal sequencing in the laboratory of Luiz Juliano, Escola Paulista de Medicina, UNIFESP, São Paulo, Brasil, or purchased from Sigma. Bovine recombinant FGF2 is a product from the laboratory of Angelo Gambarini, from our Department. 4'OH-tamoxifen, Fastdiaminobenzidine and DAPI (4',6-diamino-2phenylindole) were purchased from Sigma. Gene Porter Reagent 2 is a kit from Gene Therapy Systems, San Diego, CA, USA. The PKA inhibitor, H-89, and the MEK inhibitor, PD98059, were purchased from Calbiochem Corp., La Jolla, CA, USA.

\section{Western blotting procedures}

$\mathrm{G}_{0} / \mathrm{G}_{1}$-arrested cells, $3 \times 10^{6}$ cells per $60 \mathrm{~mm}$ dish ( $\sim 10^{5}$ cells $\left./ \mathrm{cm}^{2}\right)$, after hormonal treatment, were: (a) washed twice with cold PBS and left, for a few min, on ice to lyse in $100 \mu \mathrm{l} \mathrm{NP}-40$ buffer $(1 \%$ NP-40, 10 mM NaCl, 20 mM Tris-HCl pH 7·4, $1 \mathrm{mM} \mathrm{Na}$ ortovanadate, $2 \mu \mathrm{g} / \mathrm{ml}$ aprotinin, $2 \mu \mathrm{g} / \mathrm{ml}$ pepstatin, $1 \mu \mathrm{g} / \mathrm{ml}$ leupeptin, $1 \mathrm{mM}$ PMSF, $1 \mathrm{mM}$ dithiothreitol (DTT)); (b) scraped, transferred to an Eppendorf tube and left on ice for an additional $20 \mathrm{~min}$; and (c) spun for $20 \mathrm{~min}$ to save the supernatant. After quantification by the Bradford assay (Bradford 1976), 100 to $150 \mu \mathrm{g}$ protein from each supernatant were submitted to SDS-PAGE, electroblotted onto nylon membrane, treated with mono-specific rabbit polyclonal antibodies and then with secondary peroxidaseconjugated anti-rabbit polyclonal antibodies for chemiluminescent detection (ECL Western Blotting-Enhanced Chemiluminescence kit).

\section{BrdU incorporation}

$\mathrm{G}_{0} / \mathrm{G}_{1}$-arrested $\mathrm{Y} 1$ cells, seeded on coverslips, were incubated with hormone at zero time and then with $100 \mu \mathrm{M}$ BrdU between 12 and $24 \mathrm{~h}$; then, cells were fixed with cold methanol for $10 \mathrm{~min}$, washed three times with PBS and stored. Coverslips with fixed cells were incubated in $1.5 \mathrm{M} \mathrm{HCl}$ for $30 \mathrm{~min}$ under shaking, washed three times with PBS, inverted onto a drop $(40 \mu \mathrm{l})$ of mouse anti-BrdU antibody (Amersham Pharmacia) and incubated for $30 \mathrm{~min}$ at room temperature. After washing with PBS, immune complexes were detected with FITC-conjugated secondary antibody. Next, the coverslips were incubated with $5 \mu \mathrm{g} / \mathrm{ml}$ DAPI for $20 \mathrm{~min}$ to fluorescently stain all nuclei. Stained nuclei were examined under a Nikon Fluophot microscope using two excitation filters: UV 330-380 to visualize DAPI-stained nuclei and IF 420-490 to visualize the BrdU-labeled nuclei stained with FITC. Coverslips (two per condition in each experiment) were randomly coded, and 500-600 nuclei per coverslip were blindly counted. The raw data of independent experiments (absolute values of, respectively, labeled and unlabeled nuclei; at least two experiments) were pooled to derive a final value of the percent labeled nuclei under each condition and were statistically analyzed by Chi-square with one degree of freedom. In this analysis, $n$ (number of independent events) is the aggregated number of cells counted per each condition derived from the pooled experiments. At least 2000 nuclei were counted per condition in each set of pooled experiments and final results expressed in percent BrdU-labeled nuclei are presented in graphs and tables without standard deviation. The degree of reproducibility between independent experiments can be visualized in percent BrdU-labeled nuclei of Table 3 for all conditions of 4'OH-tamoxifen untreated cells.

\section{Immunocytochemistry for detection of nuclear c-Myc and ER proteins}

$\mathrm{G}_{0} / \mathrm{G}_{1}$-arrested cells, seeded on glass coverslips and appropriately treated with hormones, were washed with PBS and fixed in 3.7\% formaldehyde (20 min, room temperature). Fixed cells were made permeable in $1 \% \mathrm{NP}-40 / \mathrm{PBSA}\left(\mathrm{Ca}^{2+}\right.$ and $\mathrm{Mg}^{2+}$-free phosphate buffered saline) (20 min at room temperature), then blocked with $0.5 \%$ bovine serum in $0.3 \%$ Triton X-100/PBSA for $1 \mathrm{~h}$ at room temperature and then incubated with anti-c-Myc, anti-c-Fos or anti-ER (1:1000 dilution) rabbit antibodies in $1 \mathrm{mg} / \mathrm{ml}$ bovine serum albumin (BSA) $/ 0 \cdot 3 \%$ Triton X-100/PBSA, overnight at $4{ }^{\circ} \mathrm{C}$. Negative controls were cells incubated with irrelevant serum. Reagents and 
procedures from the Vectastain Elite ABC kit were used to visualize the antigen-antibody complex (nuclear labeling). The peroxidase substrate was Fast 3,3'-diaminobenzidine. Under the microscope, nuclei positive for the immune complex were stained brown, whereas negative nuclei appeared bluish when stained with Harris hematoxylin and differentiated with $\mathrm{Li}_{2} \mathrm{CO}_{3}$ saturated solution. Coverslips (two per condition in each experiment) were randomly coded, 500-600 nuclei per coverslip blindly counted under a Nikon light microscope and the raw data were pooled and statistically analyzed as described for BrdU labeling. In two cases, means ( \pm s.D.) of percent c-Myc-labeled nuclei from different sets of pooled experiments were presented in graphs and statistically analyzed by the $t$-test (Figs $1 \mathrm{C}$ and 2A). The same protocol was used for detection of c-Fos in PKA-deficient Y1 clones, using specific antibody.

\section{Y1-RasN17 conditional clonal lines}

Plasmid pMMrasDN, a construct containing the rasN17 mutant under the control of the MMTV promoter (Feig \& Cooper 1988, Cai et al. 1990), was co-transfected with the Neo gene into Y1 cells and neutrally selected with G418 to generate a series of clonal lines exhibiting dexamethasoneinducible RasN17 protein (Forti et al. 2002). In Y1-RasN17 transfectant clones, Ki-Ras-GTP constitutive high levels are essentially abolished under maximally induced RasN17 protein. But, under these same conditions, the Ras pathway remains partially functioning upon FGF2 treatment, as shown by rapid increase in Ras-GTP levels followed by ERK1/2 activation (Forti et al. 2002). Y 1- $\Delta$ Ras transfectant clones are control cell lines transfected with the empty MMTV vector.

\section{PKA-deficient Y1 clonal lines}

The plasmid pG324D, an expression vector carrying a mutated form of the PKA-regulatory subunit-1 (R1) gene under the control of the metallothionein promoter, was co-transfected with the Neo gene into Y1 cells and doubly selected with G418 and 8 BrcAMP to obtain PKA-deficient clonal lines resistant to 8 BrcAMP. Induction of PKA deficiency was not a stable phenotype among selected clones. Thus, all Y1 PKA-R1 transfectant clonal lines displayed constitutive PKA deficiency after a few culture passages, independent of the presence of metal inducers (see supplementary data, Table S1).

\section{cAMP-dependent protein kinase activity}

Y1 cells or PKA-deficient clones were seeded $\left(3 \times 10^{5}\right.$ cells $/ 35 \mathrm{~mm}$ dish $)$ in 10\% FCS and after 24 to $48 \mathrm{~h}$ they were treated with $1 \mathrm{mM}$ dibutyryl-cAMP for $1 \mathrm{~h}$. Cells were then washed in PBS and lysed in $50 \mathrm{mM}$ Tris- $\mathrm{HCl}$ (pH 7·4)/ $10 \mathrm{mM} \mathrm{MgCl}_{2} / 1 \mathrm{mM}$ DTT and protease inhibitors. After centrifugation, the supernatant was saved and $5 \mu \mathrm{l}$ aliquots were used for kinase activity reactions with $20 \mu \mathrm{Ci}\left[{ }^{32} \mathrm{P}\right] \gamma \mathrm{ATP}$ and PKA substrate, biotinylated Kemptide (Sigma), with or without PKA inhibitor for specificity testing. After 5 min incubation at $30{ }^{\circ} \mathrm{C}$, reactions were stopped with $2.5 \mathrm{M}$ guanidine hydrochloride. From each reaction, a $10 \mu \mathrm{l}$ aliquot was spotted onto a streptavidin matrix, which was then washed 4 times in $2 \mathrm{M}$ $\mathrm{NaCl}, 4$ times in $2 \mathrm{M} \mathrm{NaCl} / 1 \%$ phosphoric acid and finally in distilled water. Substrate labeled with $\left[{ }^{32} \mathrm{P}\right]$ /ATP was determined by counting the matrix in a beta-counter.

\section{Steroid extraction and quantification}

Exponentially growing Y1 cells or PKA-deficient clones in fresh medium $(0.5 \mathrm{ml})$ were stimulated with $1 \mathrm{mM}$ dibutyryl-cAMP or $0 \cdot 1 \mathrm{U} / \mathrm{ml}$ ACTH for $2 \mathrm{~h}$. The medium was then transferred to a fresh tube where $50 \mu \mathrm{l} 0.5 \mathrm{M} \mathrm{NaOH}$ and $1 \mathrm{ml}$ dichloromethane were added. Reagents were mixed and $100 \mu \mathrm{l}$ of the organic phase, obtained after centrifugation, were mixed with $1 \mathrm{ml} 65 \%$ $\mathrm{H}_{2} \mathrm{SO}_{4} / 35 \%$ ethanol. After $1 \mathrm{~h}$ incubation in the dark, steroids were quantified by fluorescence, with excitation at $470 \mathrm{~nm}$ and emission at $530 \mathrm{~nm}$.

\section{$\left[{ }^{3} \mathrm{H}\right]$ Thymidine incorporation into replicating DNA - S phase entry}

$\mathrm{G}_{0} / \mathrm{G}_{1}$-arrested $\mathrm{PKA}^{+}$or $\mathrm{PKA}^{-} \mathrm{Y} 1$ clones, in the presence or absence of $1 \mathrm{mM}$ dibutyryl cAMP, were treated with $1 \mathrm{nM}$ FGF2 for $24 \mathrm{~h}$, and $0.25 \mu \mathrm{Ci}$ $\left[{ }^{3} \mathrm{H}\right]$ thymidine/ $\mathrm{ml}$ medium was added during the last $12 \mathrm{~h}$. Cells were then washed, lysed and macromolecules precipitated and adsorbed into filters. After extensive washing with trichloroacetic acid, filters were dried and the incorporated radiation was counted in a liquid scintilation counter. 


\section{Cell proliferation assay}

$\mathrm{PKA}^{+}$or $\mathrm{PKA}^{-} \mathrm{Y} 1$ clones were seeded $\left(2 \times 10^{4} \mathrm{cells} / \mathrm{cm}^{2}\right)$ in $35-\mathrm{mm}$ diameter culture plates with 10\% FCS-DME. Twenty-four hours later, $1 \mathrm{mM}$ dibutyryl cAMP was added to medium in half of the plates. Cells from two plates/ condition were harvested daily for 8 days by trypsinization, and counted. Every other day the culture medium was changed to fresh medium.

\section{Transient transfection protocol}

Y1 cells were seeded $\left(2 \times 10^{4}\right.$ cells $\left./ \mathrm{cm}^{2}\right)$, on glass coverslips placed onto $100 \mathrm{~mm}$ dishes, in $10 \%$ FCS-DME and incubated for $24 \mathrm{~h}$. The Gene Porter Reagent 2 was used for transfections, in a ratio of $60 \mu \mathrm{l}$ transfection reagent to $12 \mu \mathrm{g}$ DNA, being $10 \mu \mathrm{g}$ pMycER or $\mathrm{p} \Delta \mathrm{MycER}$ or pBabe plus $2 \mu \mathrm{g}$ pEGFP (Enhanced Fluorescent Green Protein), in $5 \mathrm{ml}$ SFM-DME per dish. After $6 \mathrm{~h}$ incubation in SFM-DME, one volume of $20 \%$ FCS-DME was added to each dish, and this was followed by an additional $18 \mathrm{~h}$ incubation. After transfection, cells were incubated in fresh SFMDME for $48 \mathrm{~h}$ to arrest the cell cycle at the $\mathrm{G}_{0} / \mathrm{G}_{1}$ phase boundary. Before hormonal treatment, cells were incubated for $30 \mathrm{~min}$ with $200 \mathrm{nM}$ 4'OH-tamoxifen to induce nuclear migration of the MycER fusion protein. Then, FGF2 and/or ACTH were added to the medium, left for $12 \mathrm{~h}$, followed by the addition of BrdU for a further $12 \mathrm{~h}$. Efficiency of transfection was monitored by two criteria. First, prior to 4'OH-tamoxifen addition, two coverslips per dish were analyzed under the fluorescence microscope to estimate the percentage of EGFP-positive cells; valid experiments displayed 70-80\% EGFP fluorescent cells. Secondly, transfection efficiency was also immunocytochemically estimated by nuclear labeling with anti-ER in cells treated with 4'OH-tamoxifen for $4.5 \mathrm{~h}$; experiments displaying less than $70 \%$ labeled nuclei were not considered.

\section{Results}

\section{ACTH and FGF2 antagonistically converge to promote, respectively, degradation and stabilization of the c-Myc protein}

Forty-eight hours of serum starvation causes an accentuated cell cycle arrest in Y1 adrenocortical cells at the $G_{0} / G_{1}$ boundary, correlating with a strong decrease in $\mathrm{c}-\mathrm{Myc}$ protein expression to low, but persistent, basal levels. FGF2 is a robust mitogen for $G_{0} / G_{1}$-arrested $Y 1$ cells, that at $1 \mathrm{nM}$, up-regulates c-Myc protein levels by about fivefold in terms of protein/cell as assessed by Western blotting assays (Fig. 1A and B) or by twofold in terms of percent labeled nuclei as assessed by immunocytochemistry (Fig. 1C). c-Myc upregulation elicited by FGF2 is completely inhibited by $50 \mu \mathrm{M}$ PD98059, a specific inhibitor of MEK1 (Fig. 1E), implying that this FGF2 effect is mediated by activation of the ERK1/2 MAP kinases. However, PD98059 has no effect on c-Myc basal levels, assayed by immunocytochemistry (Fig. 1E). On the other hand, the PI3K inhibitor, wortmannin, causes a drastic reduction of c-Myc basal levels (Fig. 1D), suggesting that basal and induced levels of c-Myc are under separate regulation.

ACTH, at physiological concentrations, antagonizes the FGF2 stimulatory effect (Fig. 2A, B and $\mathrm{G})$, causing a sharp decrease in c-Myc-induced levels within 30 to $45 \mathrm{~min}$ after its addition to the medium, detected by immunocytochemistry (Fig. 2B) and by Western blotting (Fig. 2C). The mitogenic response of $\mathrm{Y} 1$ cells triggered by FGF2 includes a late induction of the cyclin D1 protein, which depends on protein synthesis and peaks between 5 and $6 \mathrm{~h}$ of treatment (Schwindt et al. 2003). ACTH, in spite of causing a sharp decrease in c-Myc levels, does not interfere with cyclin D1 induction (Fig. 2D), indicating that induction of c-Myc and cyclin D1 is not correlated.

Northern blotting assays show that $G_{0} / G_{1}$ arrested Y1 cells display significant basal levels of the c-myc mRNA, consistent with a minor deregulation of c-myc gene transcription that we have previously demonstrated by run-on transcription experiments (Rocha et al. 2003). FGF2 causes a $2 \cdot 5$-fold elevation in steady state levels of c-myc mRNA irrespective of ACTH treatment (supplementary data, Fig. S1A). In addition, inhibition of RNA synthesis with actinomycin D (supplementary data, Fig. S1B) has allowed us to follow the kinetics of c-myc mRNA degradation by Northern blots in $\mathrm{Y} 1$ cells treated with FGF2 and/or ACTH (supplementary data, Fig. S1G). Table 1 displays estimates of c-myc mRNA half-life obtained from these kinetic experiments, showing a short half-life (16 to $22 \mathrm{~min}$ ) and no significant differences between Y1 cells untreated and treated with FGF2 
A

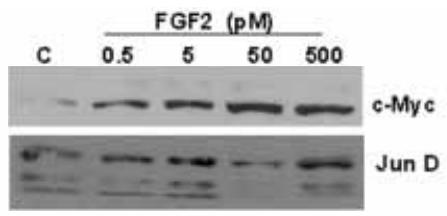

B

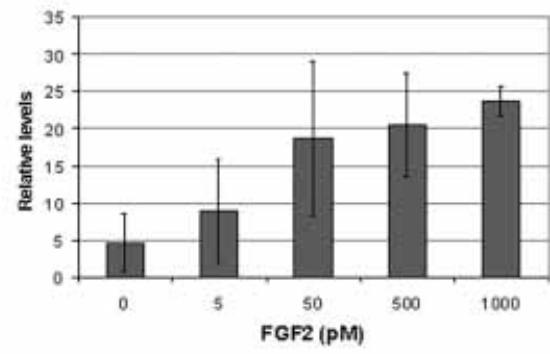

C

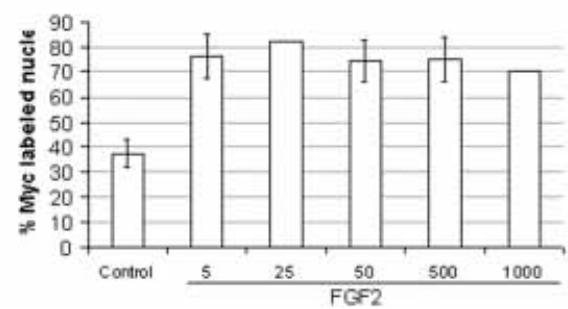

D
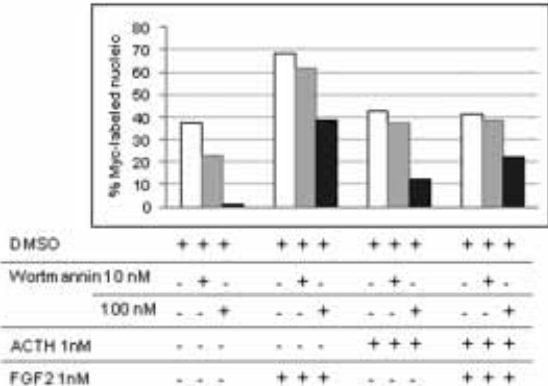

E

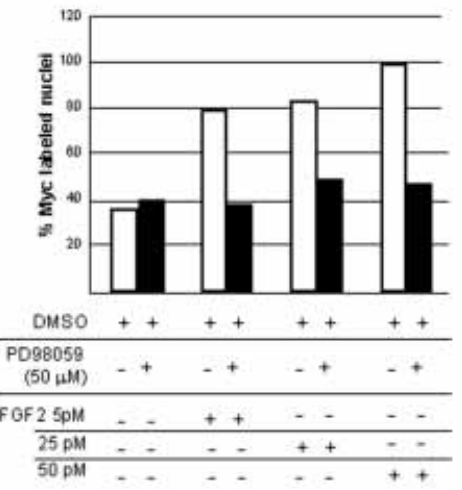

Figure 1 Induction of c-Myc protein expression by FGF2 in $G_{0} / G_{1}$-arrested $Y 1$ adrenocortical cells. Determination of dose-response curves by Western blot and immunocytochemical assays and inhibition of PI3K and MEK1 pathways by, respectively, wortmannin and PD98059 inhibitors. $G_{0} / G_{1}$-arrested $Y 1$ adrenocortical cells were treated with FGF2 and/or ACTH for $4 \mathrm{~h}$ and processed to estimate c-Myc protein levels by Western blot or immunocytochemistry; wortmannin or PD98059 were added 30 min prior to treatment with FGF2 for $4 \mathrm{~h}$. (A) A representative Western blot to determine FGF2 dose-response curve of C-Myc induction; JunD protein, whose expression is constant, is used as an internal reference. (B) FGF2 dose-response curve determined by densitometry of 4 independent Western blot assays of c-Myc levels (means \pm S.D.). (C) FGF2 dose-response curve determined by 3 independent immunocytochemical assays of percent c-Myc-labeled nuclei (means \pm S.D.). (D) Effect of the PI3K inhibitor, wortmannin. (E) Effect of the MEK1 inhibitor, PD98059.

and/or ACTH. These results suggest, first, that FGF2 increases transcription rate to cause an elevation in c-myc mRNA steady state levels and, secondly, that the antagonism between FGF2 and ACTH must be restricted to the control of c-Myc protein levels, probably by regulation of synthesis/ degradation balance.

To test whether ACTH and FGF2 actually regulate c-Myc protein half-life in opposite directions, we measured c-Myc degradation rates after blocking protein synthesis with cycloheximide, estimating c-Myc protein levels by both the percent Myclabeled nuclei assessed by immunocytochemistry (Fig. 3) and by densitometric analysis of Western blots (supplementary data, Fig. S2). After protein synthesis inhibition, degradation of c-Myc, or any other specific protein, should follow first order kinetics. Therefore, a semi-log plot of c-Myc levels (log scale) as a function of time (linear scale) must fit into a straight line, the slope of which allows the estimation of c-Myc protein half-life (Fig. 3). Table 2 shows a series of estimates of c-Myc half-life in Y1 cells under different conditions - immunocytochemistry and Western blot assays have yielded close results. In SFM, c-Myc displays a short half-life (nearly 20 min; see Table 2); FGF2 and FCS stabilize c-Myc increasing its half-life by four- to fivefold, reaching 91 to $118 \mathrm{~min}$ (Table 2). On the other hand, Table 2 shows that ACTH destabilizes c-Myc protein causing a two- to three-fold decrease in 
A

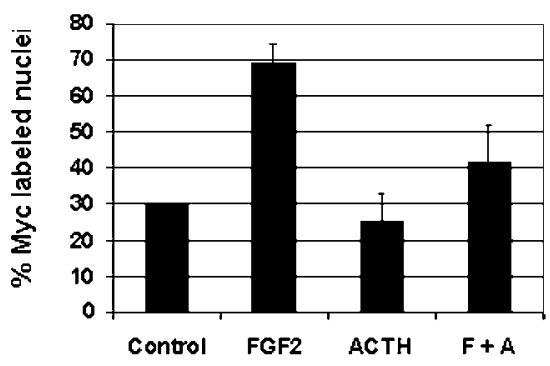

B

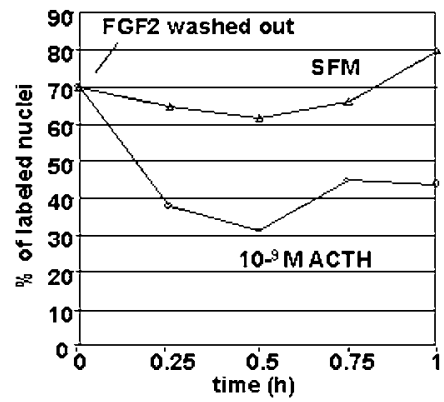

C

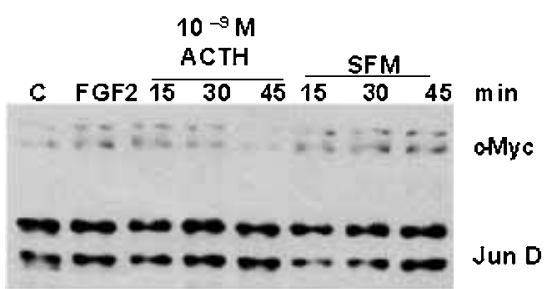

D

Figure 2 ACTH inhibition of c-Myc induction by FGF2 in $G_{0} / G_{1}$-arrested $Y 1$ adrenocortical cells. (A) Effect of $1 \mathrm{nM}$ FGF2 and/or $1 \mathrm{nM}$ ACTH treatment for $4 \mathrm{~h}$; the results are a pool of 5 independent immunocytochemical assays (means \pm S.D.). (B and C) c-Myc induction by $1 \mathrm{nM}$ FGF2 treatment for $4 \mathrm{~h}$, followed by $1 \mathrm{nM} \mathrm{ACTH}$ or SFM, as shown by immunocytochemical (B) or Western blot (C) assay. (D) Cyclin D1 induction by $1 \mathrm{nM}$ FGF2 and/or $1 \mathrm{nM} \mathrm{ACTH}$ treatment for $5 \mathrm{~h}$. F+A, FGF2+ACTH.

Table 1 Stability of the c-myc mRNA is not significantly affected by FGF2 and/or ACTH in Y1 adrenocortical cells kept in SFM

\section{Half-life ( $\min )$ by Northern blot assays}

\section{Additions to SFM}

FGF2 (0.5 nM; $3 \mathrm{~h})$

ACTH (1 nM; $3 \mathrm{~h})$

FGF2+ACTH (3 h)
$15 \cdot 9 \pm 2 \cdot 2(n=2)$

$18 \cdot 3 \pm 6 \cdot 6(n=2)$

$17 \cdot 4 \pm 7 \cdot 8(n=4)$

$22 \cdot 1 \pm 8 \cdot 9(n=2)$

$\mathrm{G}_{0} / \mathrm{G}_{1}$-arrested $\mathrm{Y} 1$ adrenocortical cells (48 $\mathrm{h}$ in SFM) were treated with FGF2 and/or ACTH for $3 \mathrm{~h}$ (as indicated in the Table) and then with $5 \mathrm{\mu g} / \mathrm{ml}$ actinomycin $D$ to inhibit more than $98 \%$ of RNA synthesis. After actinomycin D addition, $\mathrm{Y} 1$ cultures were periodically harvested and processed to estimate the decay rate of the c-myc mRNA by Northern blot assays (see Fig. S1). Half life figures shown in the Table were obtained from semi-log plots of relative values of c-myc mRNA steady state levels (densitometric measurements of Northern blots; see Fig. S1) as a function of time, after actinomycin D addition. Differences between half life values displayed in the Table are not statistically significant ( $t$-test).

half-life for $\mathrm{Y} 1$ cells maintained in $\mathrm{SFM}+\mathrm{ACTH}$ (13 min), SFM+FGF2+ACTH (43 min) and 10\% FCS+ACTH (34 min). Altogether, these results support two conclusions: (a) Y1 tumor cells retain regulatory mechanisms to balance synthesis and degradation of the c-Myc protein and (b) FGF2 promotes stabilization and ACTH degradation of the c-Myc protein.

As c-Myc is known to be part of a network of transcription regulators, we decided to investigate the expression of other proteins from the Myc/ Max/Mad network (Grandori et al. 2000). RTPCR experiments with total RNA from Y1 cells amplify specific sequences for max, mad-1, mad-4 and mxi (not shown). In addition, Western blots and immunocytochemistry assays of $\mathrm{G}_{0} / \mathrm{G}_{1}$ arrested $\mathrm{Y} 1$ cells indicate that expression levels of the Max, Mad-1, Mad-4 and Mxi proteins are constant irrespective of FGF2 or ACTH treatment (supplementary data, Fig. S3). Thus, ACTH and FGF2 antagonistically regulate the availability of the c-Myc protein, but not of the Max and Mad proteins, in Y1 adrenocortical cells. 


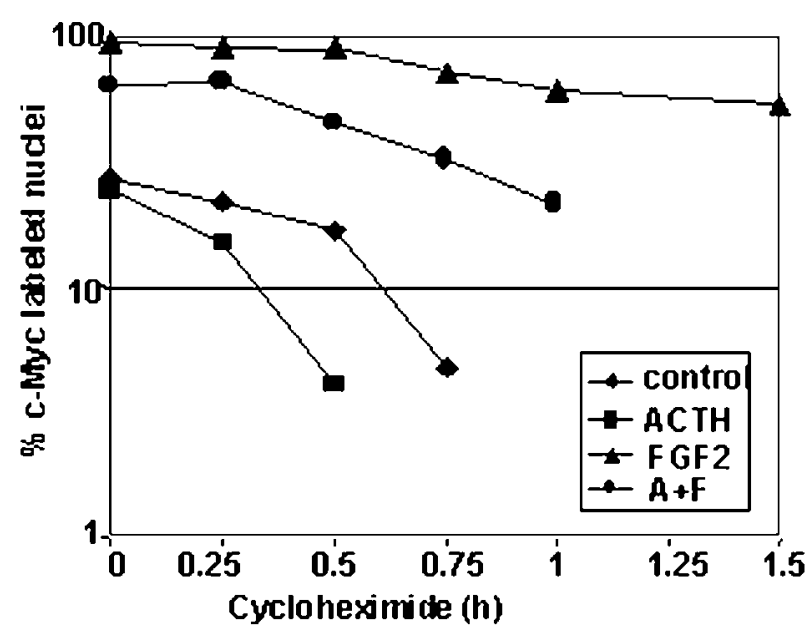

Figure 3 Determination of $\mathrm{c}-\mathrm{Myc}$ protein half-life by immunocytochemistry. $G_{0} / G_{1}$-arrested $Y 1$ adrenocortical cells plated onto coverslips and maintained in SFM, were treated with FGF2 (1 nM) and/or ACTH (1 nM) for $4 \mathrm{~h}$, after which $10 \mu \mathrm{g} / \mathrm{ml}$ cycloheximide were added to the medium. Pairs of coverslips were taken at the indicated periods of time, and cells were fixed and analyzed for c-Myc expression by

immunocytochemistry. Each point of percent Myc-labeled nuclei resulted from counting 1000 cells (500 cells per coverslip). The semi-log plot shown in the Figure comes from one representative experiment. The curves for FGF2 and FGF2+ACTH $(\mathrm{A}+\mathrm{F})$ display, respectively, 5 and 4 points that fit well into straight lines, and the slopes yield reliable estimates of half-life. The curves for Control (untreated cells) and ACTH contain fewer points and give poor estimates of half-life.

\section{Constitutive c-Ki-ras-GTP underlies partial deregulation of the c-myc gene activity and ACTH anti-mitogenic effects}

Y1 cells over-express c-Ki-ras proto-oncogene (Schwab et al. 1983, Kimura \& Armelin 1988), displaying high constitutive levels of c-Ki-Ras-GTP (Forti et al. 2002). To analyze the phenotypic effects of the constitutive c-Ki-Ras-GTP levels, we developed transfectants of Y1 cells carrying the dominant negative mutant, HaRasN17 (Feig \& Cooper 1988), under the control of the MMTV conditional promoter. In these $\mathrm{Y} 1$ transfectants, dexamethasone induces the HaRasN17 transgene causing attenuation of the c-Ki-Ras-GTP levels leading to cell phenotype changes (Forti et al. 2002).

Figure 4 shows results of $\mathrm{c}-\mathrm{Myc}$ induction and DNA synthesis stimulation by FGF2 and/or ACTH, in $\mathrm{G}_{0} / \mathrm{G}_{1}$-arrested cells of three Y1 transfectant clones, namely RasN17-1.5 (Fig. 4B and E), RasN17-3.1 (Fig. 4C and F) and $\Delta$ Ras3.3, a control clone carrying the MMTV-vector devoid of the rasN17 mutant gene (Fig. 4D and G). First, Fig. 4A displays Western blots showing high levels of the human RasN17 mutant protein induced by dexamethasone in RasN17-1.5 and $3 \cdot 1$ cells, but not in $\Delta$ Ras $3 \cdot 3$ cells. These Western blots also show leakage of the MMTV promoter leading to significant basal expression of the RasN17 protein in dexamathasone untreated cells of both RasN17$1 \cdot 5$ and RasN17-3.1 clones. However, the ratios between dexamethasone-induced levels and the basal RasN17 protein levels are enormous. Secondly, dexamethasone has no effect on c-Myc induction (Fig. 4D) and S phase entry (Fig. 4G) in $\Delta$ Ras3.3 cells that exhibit the regular pattern of antagonistic interaction between FGF2 and ACTH found in parental Y1 cells, irrespective of dexamethasone treatment. Thirdly, dexamethasone treatment reduces c-Myc expression and DNA synthesis to negligible basal levels in $G_{0} / G_{1}$ arrested cells of the RasN17-1.5 (Fig. 4B and E) and RasN17-3.1 (Fig. 4G and F) sub-lines. Fourthly, dexamethasone treatment changes the pattern of response of RasN17-1.5 and RasN173. 1 clones to ACTH, but not to FGF2: (a) in the absence of dexamethasone, cells from both sub-lines behave like $\Delta \mathrm{Ras} 3 \cdot 3$ cells, responding to FGF2 with a large stimulation of c-Myc expression (8- to 30-fold increase; Fig. 4B and $\mathrm{G}$ ) and $\mathrm{S}$ phase entry (2.5- to 5 -fold increase; Fig. $4 \mathrm{E}$ and F), that is strongly inhibited by ACTH (50 to $80 \%$ inhibition of c-Myc induction, Fig. $4 \mathrm{~B}$ and $\mathrm{C} ; 70$ to $80 \%$ inhibition of $\mathrm{S}$ phase entry, Fig. $4 \mathrm{E}$ and $\mathrm{F}$ ); (b) in the presence of dexamethasone, FGF2 still triggers a robust induction of c-Myc expression ( $>10$-fold increase, Fig. $4 \mathrm{~B}$ and $\mathrm{C}$ ) and $\mathrm{S}$ phase entry (3- to 8-fold increase, Fig. 4E and F), but ACTH has negligible (Fig. 4B) to small inhibitory effects (20 to $35 \%$ inhibition, Fig. 4C, E and F) on both c-Myc induction and $\mathrm{S}$ phase entry.

In conclusion, constitutive high levels of Ki-RasGTP are sufficient to partially deregulate transcription of the c-myc gene, leading to significant basal expression of c-myc mRNA and c-Myc protein in $\mathrm{G}_{0} / \mathrm{G}_{1}$-arrested $\mathrm{Y} 1$ adrenocortical cells. FGF2 causes an increase in c-myc-mRNA steady state levels (supplementary data, Fig. S1A) and stabilization of the c-Myc protein (Table 2), through a process mediated by ERK-MAP kinases activation (Fig. 1E) and independent of constitutive high levels 
Table 2 c-Myc protein is stabilized by FGF2 and FCS and destabilized by ACTH in Y1 adrenocortical cells

\begin{tabular}{|c|c|c|c|}
\hline \multirow[b]{3}{*}{ Media } & \multirow[b]{2}{*}{ Additions to media } & \multirow[b]{2}{*}{ Western blot assay } & \multirow[b]{2}{*}{ Immunocytochemistry assay } \\
\hline & & & \\
\hline & & & \\
\hline \multirow[t]{4}{*}{ SFM } & - & $20(n=1)^{\mathrm{a}}$ & $19 \pm 1(n=2)^{\mathrm{d}}$ \\
\hline & FGF2 & $103 \pm 17(n=3)^{\mathrm{b}}$ & $118 \pm 10(n=3)^{\mathrm{e}}$ \\
\hline & ACTH & $13(n=1)^{\mathrm{c}}$ & $13 \pm 1(n=2)^{f}$ \\
\hline & FGF2+ACTH & ND & $43 \pm 9 \cdot 5(n=3)^{9}$ \\
\hline \multirow[t]{3}{*}{$10 \%$ FCS } & - & $91 \pm 24(n=2)^{\mathrm{h}}$ & ND \\
\hline & FGF2 & $78(n=1)^{i}$ & ND \\
\hline & ACTH & $34 \pm 2(n=2)^{\mathrm{j}}$ & ND \\
\hline
\end{tabular}

$\mathrm{G}_{0} / \mathrm{G}_{1}$-arrested (48 $\mathrm{h}$ in SFM) and/or exponentially growing (10\% FCS) Y1 adrenocortical cells were treated with FGF2 $(0.5 \mathrm{nM})$ and/or ACTH $(1 \mathrm{nM})$ for $4 \mathrm{~h}$ and then with $10 \mu \mathrm{g} / \mathrm{ml}$ cycloheximide to inhibit more than $95 \%$ of protein synthesis. After cycloheximide addition, $\mathrm{Y} 1$ cultures were periodically harvested and processed for Western blot (see Fig. S2) and/or immunocytochemistry assays (Fig. 2). Values of half-life shown in the Table were obtained from semi-log plots in which c-Myc levels were determined by densitometry of Western blots (see Fig. S2) and/or by counting \% c-Myc-labeled nuclei in immunocytochemistry assays (Fig. 3). Half-life values determined by Western blots are in close agreement with those obtained by immunocytochemistry assays: for instance, for cells maintained in SFM+FGF2 the difference between half-life determined by Western blot (b) and by immunocytochemistry (e) is not statistically significant $(P \leq 0.364 ; t$-test). In addition, differences between half-life values for cells in $10 \%$ FCS (h), 10\% FCS+FGF2 (i) and SFM+FGF2 (b and e) are also not statistically significant. On the other hand, in SFM, the difference between half-life values for FGF2 (b and e) and for FGF2+ACTH $(\mathrm{g})$ is statistically significant $(P \leq 0.0005$; $t$-test). In SFM and SFM+ACTH c-Myc half-life (13 to $20 \mathrm{~h})$ is much lower than in 10\% FCS (91 h) or in SFM+FGF2 (103 to $118 \mathrm{~h}$ ), but the values of half-life for SFM and SFM+ACTH are not as accurate as in other experimental conditions displayed in this Table (see Fig. 3 and supplementary data, Fig. S2), ND, not done.

of Ki-Ras-GTP (Fig. 4B, G and D). On the other hand, ACTH strongly destabilizes the c-Myc protein (Table 2) to inhibit FGF2 mitogenic activity (Fig. 4E, $\mathrm{F}$ and $\mathrm{G})$, but by a process dependent on constitutive high levels of Ki-Ras-GTP (Fig. 4B, C and D).

\section{ACTH destabilizes the c-Myc protein via the cAMP/PKA pathway}

Several clones resistant to dibutyryl-cAMP were derived from the $\mathrm{Y} 1$ adrenocortical cell line by stable transfection with an expression vector carrying a mutated form of the PKA-regulatory subunit-1 that does not bind cAMP (see Materials and methods section). Three of these clones, G1, G4 and G5, show: (a) very low activity of PKA, (b) lack of c-Fos protein induction and steroidogenesis stimulation by dibutyryl-cAMP, and (c) resistance to dibutyryl-cAMP inhibition of both DNA synthesis stimulation and cell proliferation (see Table S1 at http://jme.endocrinologyjournals.org/content/vol33/issue3/).

ACTH treatment of the PKA-deficient Y1-G1 clone, after stimulation with FGF2 for $4 \mathrm{~h}$, does not cause the reduction in c-Myc protein levels observed in parental wild type Y1 cells (compare Fig. 5A with Fig. 2B). In addition, concomitant treatment of the Y1-G1 clone with FGF2 and ACTH or dibutyryl-cAMP does not lead to inhibition of c-Myc induction by FGF2 (Fig. 5B). Similar results were observed with the other two PKA-deficient clones, namely, Y1-G4 and Y1-G5 (not shown). Furthermore, in parental Y1 cells the PKA inhibitor, H89, blocks the reduction in c-Myc levels promoted by ACTH (Fig. 5G). Altogether, these results imply that the destabilization of the c-Myc protein caused by ACTH is a process mediated by the cAMP/PKA pathway.

\section{Sustained expression of the c-Myc protein is sufficient to abolish the negative effect of ACTH over FGF2 mitogenicity in $G_{0} / G_{1}$-arrested $Y 1$ adrenocortical cells}

To test the hypothesis that down-regulation of c-Myc by ACTH is sufficient to block the cell cycle and, by way of consequence, antagonize the mitogenic action of FGF2, we have transiently 
A Induction of the RasN17 protein by dexamethasone

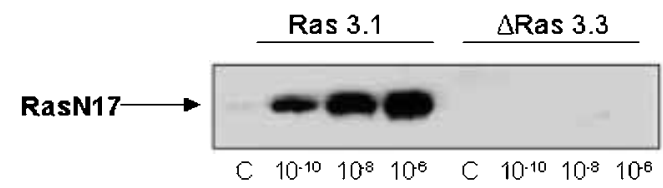

B

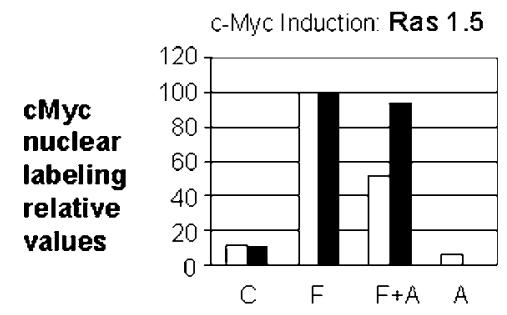

E

Sphase entry: Ras 1.5

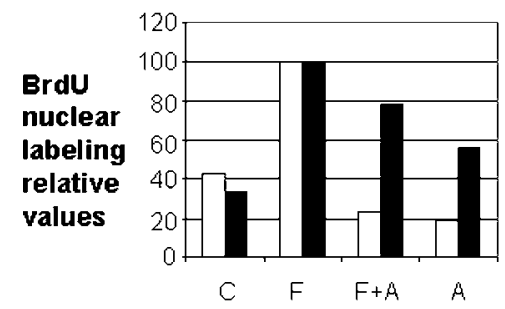

C

C-Mycinduction: Ras 3.1

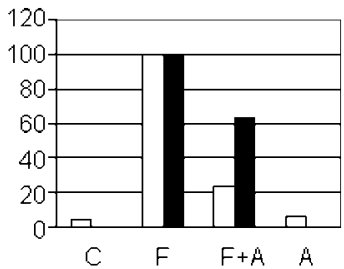

$\mathbf{F}$

S phase entry: Ras 3.1

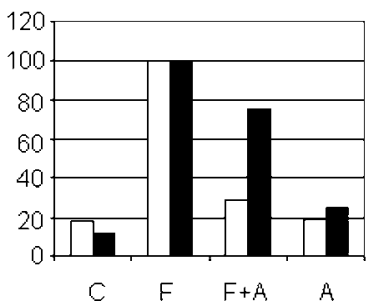

Ras 3.1 Ras 1.5

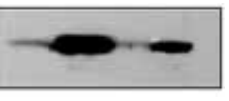

C $10^{6}$ C $10^{-8}$

D

c-Myc Induction: $\Delta$ Ras 3.3

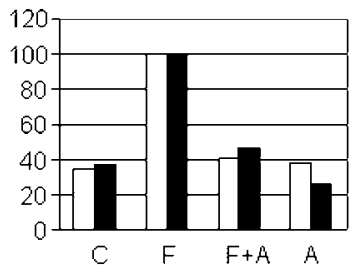

G

S phase entry: $\Delta$ Ras 3.3

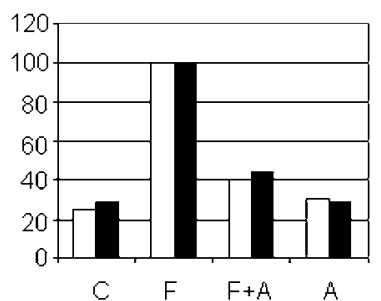

Figure 4 ACTH inhibitory effects on c-Myc induction and $S$ phase entry promoted by FGF2 in transfectant clones of Y1 adrenocortical cells carrying the human Ha-rasN17 mutant gene under the control of the MMTV conditional promoter, whose activity was induced by dexamethasone treatment. $G_{0} / G_{1}$-arrested cells from clones RasN17-1.5, RasN17-3.1 and $\Delta$ Ras3.3 (carrying empty vector) were treated or untreated with dexamethasone (dexa) $24 \mathrm{~h}$ prior to stimulation with $1 \mathrm{nM}$ FGF2 $(\mathrm{F})$ and/or $1 \mathrm{nM} \mathrm{ACTH}(\mathrm{A})$. To estimate c-Myc induction, cells were fixed after $4 \mathrm{~h}$ of stimulation with FGF2 and/or ACTH and processed for immunocytochemical assay. To monitor S phase entry, cells incorporated BrdU between 12 and $24 \mathrm{~h}$ of stimulation with FGF2 and/or ACTH and were processed to determine the percentage of BrdU-labeled nuclei. (A) Western blots with mono-specific antibody for the human RasN17 protein to demonstrate basal and dexamethasone $(24 \mathrm{~h}$ )-induced levels of the RasN17 protein. C, control untreated cells. Values of percent $\mathrm{C}-\mathrm{Myc}$-labeled nuclei $(\mathrm{B}, \mathrm{C}$ and $\mathrm{D})$ and percent BrdU-labeled nuclei $(\mathrm{E}, \mathrm{F}$ and $\mathrm{G})$ were pooled from 2 independent experiments (about 1000 nuclei counted per each condition) and normalized making $F=100$ in all cases, for both dexamethasone-treated and untreated cells. The actual values of $F$ in each case for, respectively, minus and plus dexamethasone are: (B) $55 \%$ and $33 \%$; (C) $73 \%$ and $27 \%$; (D) $57 \%$ and $63 \%$; (E) $52 \%$ and $21 \%$; (F) $42 \%$ and $20 \%$; (G) $39 \%$ and $40 \%$. Differences in data set (either in terms of percent C-Myc-labeled nuclei or percent BrdU-labeled nuclei) were analyzed by $\chi^{2}$ statistics with one degree of freedom. In all cases, differences between F (FGF2 treated) and C (untreated cells) were very large and, as expected, statistically significant $(P<0.001)$, irrespective of dexamethasone treatment. In the case of the $\Delta$ Ras3.3 clone, for each condition displayed in $\mathrm{D}$ (c-Myc induction) and G (S phase entry), differences between dexamethasone-treated (solid bars) and untreated (open bars) cells were very small and not statistically significant, showing that dexamethasone treatment, per se, has no effect on $Y 1$ cell response to either FGF2 or ACTH. In RasN17-1.5 and RasN17-3.1 clones without dexamethasone treatment, differences between $\mathrm{F}$ and $\mathrm{F}+\mathrm{A}$ were very large and statistically significant $(P<0.001)$. However, dexamethasone treatment sharply reduced ACTH inhibitory effects on both c-Myc induction and S phase entry in RasN17-1.5 and RasN17-3.1 clones; thus, the difference between F and F+A for c-Myc induction (RasN17-1.5, B) was negligible and not statistically significant; in addition, differences between $\mathrm{F}$ and $\mathrm{F}+\mathrm{A}$ for $\mathrm{C}-\mathrm{Myc}$ induction (RasN17-3.1, C) and for S phase entry (RasN17-1.5, E; RasN17-3.1, F) were small, but statistically significant $(P<0.01)$. 

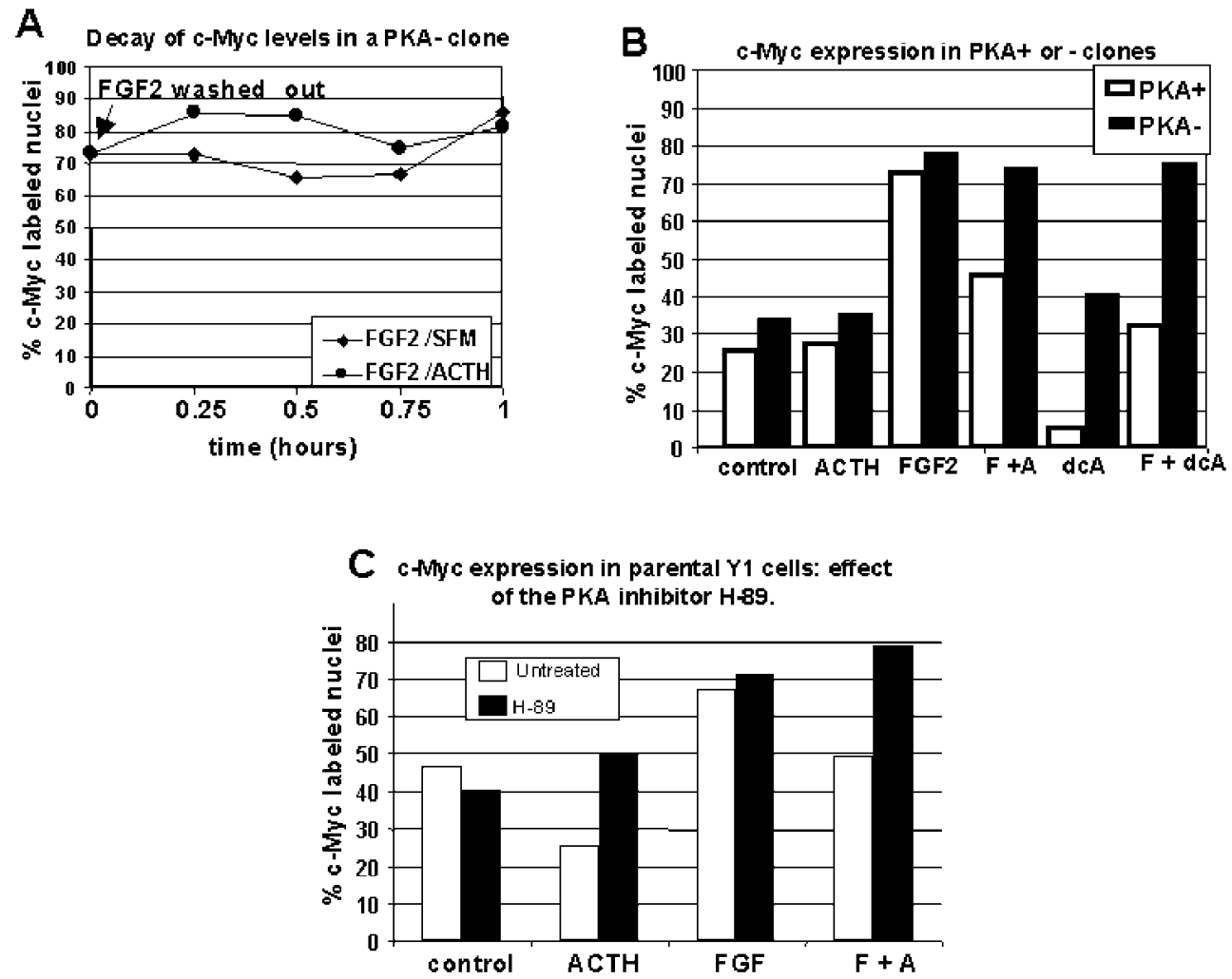

Figure 5 Inhibition of c-Myc expression by $A C T H$, in $G_{0} / G_{1}$-arrested $Y 1$ adrenocortical cells, is mediated by the cAMP-PKA pathway. (A) PKA- cloneY1-G1 was submitted to ACTH (1 nM) after FGF2 treatment (1 nM, 4 h). (B) PKA- clone Y1-G1 and PKA+ clone $\mathrm{Y} 1-\Delta \mathrm{G} 1$ (carrying empty vector) were treated for $4 \mathrm{~h}$ with ACTH (1 nM), FGF2 (1 nM) and dibutyryl-cAMP (1 mM) as indicated. (C) Y1 parental cells were treated with the PKA specific inhibitor, H89 $(50 \mu \mathrm{M})$, starting $30 \mathrm{~min}$ before addition of ACTH $(4 \mathrm{~h}, 1 \mathrm{nM})$ and/or FGF2 (4 h, $1 \mathrm{nM}$ ). c-Myc levels (\% Myc-labeled nuclei) were estimated by immunocytochemistry. F, FGF2; A, ACTH; dcA, dibutyryl-cAMP.

transfected the gene for the MycER chimera into $\mathrm{Y} 1$ cells and induced its activity (migration to nucleus) with 4'OH-tamoxifen. This approach fulfils all requirements to conclusively test this hypothesis. First, the efficiency of transfection monitored by EGFP expression reached $75 \%$ $\pm 5 \cdot 4$ EGFP positive cells per coverslip. Secondly, the MycER protein (and for that matter also the $\triangle \mathrm{MycER}$ protein) is constitutively expressed and retained in the cytoplasm, migrating to the nucleus only under induction with 4'OH-tamoxifen (Fig. 6A). ER-nuclear labeling was between 60 and 70\% upon 4'OH-tamoxifen induction (Fig. 6A), leading to $80 \%$ Myc-labeled nuclei in Y1 cells treated with both FGF2 and ACTH (Fig. 6B). On the other hand, in $\mathrm{Y} 1$ cells transfected with the empty vector, pBabe, 4'OH-tamoxifen induction yielded less than
10\% ER-labeled nuclei (Fig. 6A) and had no effect on the pattern of endogenous c-Myc expression upon FGF2 and/or ACTH treatment (Fig. 6B).

Table 3 shows data of $\mathrm{S}$ phase entry from experiments in which Y1 cells were, first, transfected with pBabe (empty vector), $\mathrm{p} \Delta \mathrm{MycER}$ (defective Myc) or pMycER at $-60 \mathrm{~h}$, secondly, transferred to serum-free medium at $-48 \mathrm{~h}$ to arrest cell cycle, thirdly, treated with 4'OHtamoxifen at $-0.5 \mathrm{~h}$ to induce both $\triangle \mathrm{MycER}$ and MycER and, finally, fourthly, stimulated with FGF2 or ACTH or both to promote $G_{1}$ phase traversing and $\mathrm{S}$ phase entry (initiation of DNA synthesis). In Y1 cells transfected with pBabe (empty vector) or with $\mathrm{p} \Delta \mathrm{MycER}$ (defective Myc), ACTH reduces the mitogenic activity of FGF2, irrespective of 4'OH-tamoxifen treatment, as 
A
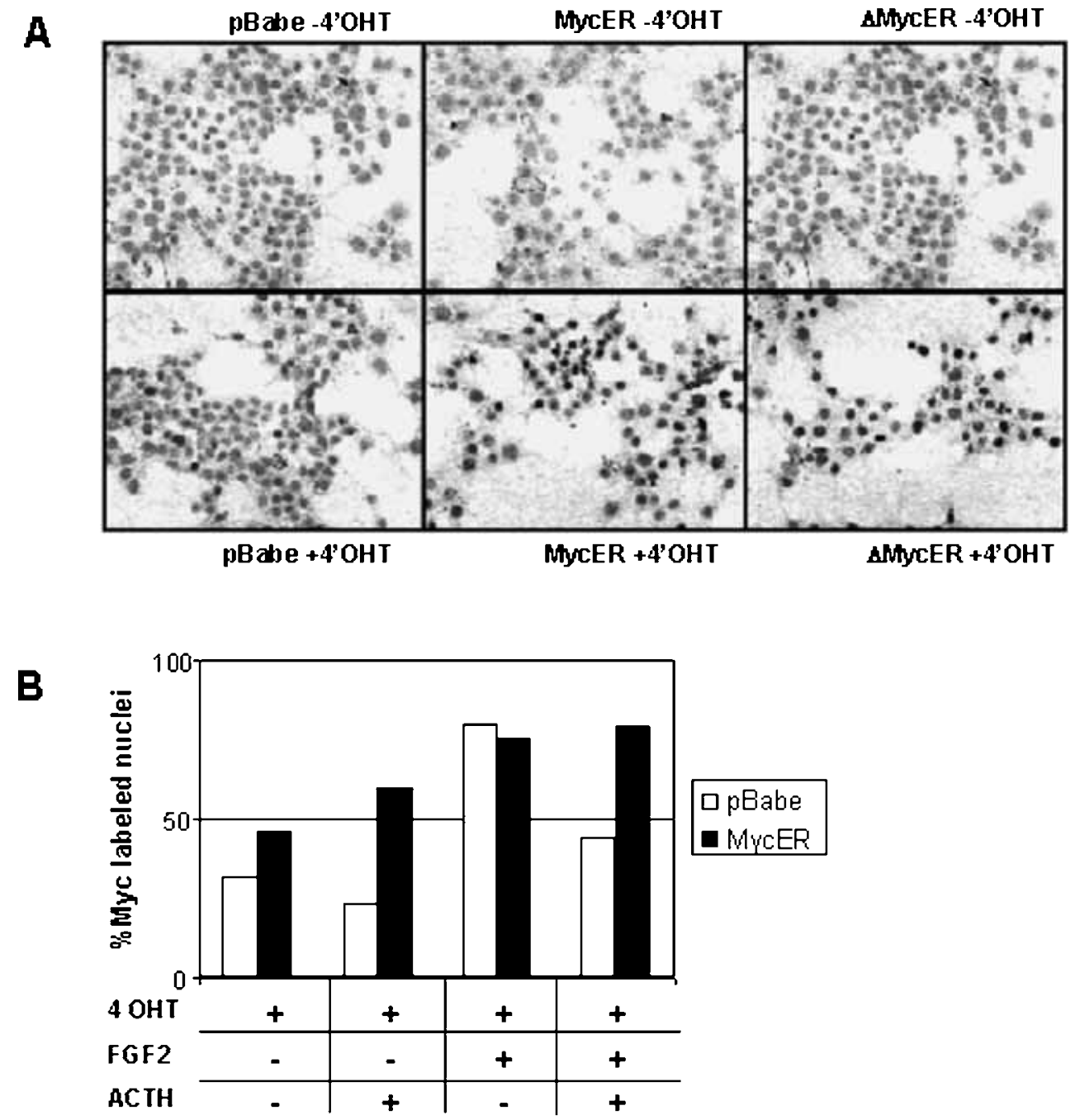

Figure 6 Immuno-detection of estrogen receptor (ER) and c-Myc in nuclei of Y1 adrenocortical cells transiently transfected with MycER chimeras. $Y 1$ cells were transfected with pBabe, MycER or $\triangle \mathrm{MycER}$ and then starved of serum in SFM, as detailed in the Materials and methods section. Then, $200 \mathrm{nM}$ 4'OH-tamoxifen (+ or - 4'OHT) were added to $\mathrm{G}_{0} / \mathrm{G}_{1}$-arrested $\mathrm{Y} 1$ cells, $0.5 \mathrm{~h}$ before the addition of FGF2 ( $\left.4 \mathrm{~h}, 1 \mathrm{nM}\right)$ and/or ACTH $(4 \mathrm{~h}, 1 \mathrm{nM})$. Finally, cells were fixed and immunocytochemically processed to detect ER or c-Myc-labeled nuclei. (A) ER-labeled nuclei; for staining procedures see Materials and methods section; magnification $\times 250$. (B) Percent c-Myc-labeled nuclei.

expected (Table 3). In contrast, in Y1 cells transfected with pMycER, 4'OH-tamoxifen induction leads to high sustained c-Myc expression (up to $80 \%$ c-Myc-labeled nuclei) and renders cells resistant to the negative effect of ACTH over FGF2 mitogenic stimulation (Table 3).

The results in Table 3 also show that sustained high levels of c-Myc are sufficient to abolish the ACTH anti-mitogenic effect over FGF2, but are not, per se, sufficient to promote $\mathrm{G}_{1}$ phase traversing and $\mathrm{S}$ phase entry in $\mathrm{G}_{0} / \mathrm{G}_{1}$-arrested $\mathrm{Y} 1$ cells, treated or untreated with ACTH.

\section{Discussion}

\section{Cell cycle regulatory pathways in Y1 adrenocortical cells}

A large amplification of the c-Ki-ras proto-oncogene (Schwab et al. 1983, Kimura \& Armelin 1988) causes 
Table 3 Sustained expression of c-Myc abolishes ACTH inhibitory effect over FGF2 mitogenic activity, as shown by transient transfection of pMycER, $p \Delta M y c E R$ and $p B a b e$, in $G_{0} / G_{1}$-arrested $Y 1$ adrenocortical cells

\begin{tabular}{|c|c|c|c|c|c|}
\hline & $\begin{array}{l}\text { Induction } 4{ }^{\prime} \mathrm{OHT} \\
t=-0.5 \mathrm{~h}\end{array}$ & $\begin{array}{l}\text { FGF2 } \\
\mathrm{t}=0 \mathrm{~h}\end{array}$ & $\begin{array}{l}\text { ACTH } \\
\mathrm{t}=0 \mathrm{~h}\end{array}$ & $\begin{array}{l}\% \text { BrdU-labeled nuclei } \\
t=24 \mathrm{~h}\end{array}$ & $\begin{array}{l}\text { ACTH } \\
\text { inhibition (\%) }\end{array}$ \\
\hline $\begin{array}{l}\text { Transfecti } \\
t=-66 h\end{array}$ & & & & & \\
\hline pBabe & - & - & - & $30 \cdot 1$ & 42 \\
\hline & - & + & - & $75 \cdot 3$ & \\
\hline & - & - & + & $25 \cdot 7$ & \\
\hline & - & + & + & 43.5 & \\
\hline & + & - & - & $25 \cdot 7$ & 45 \\
\hline & + & + & - & 74.1 & \\
\hline & + & - & + & $27 \cdot 2$ & \\
\hline & + & + & + & 41.0 & \\
\hline pMycER & - & - & - & 29.5 & 41 \\
\hline & - & + & - & 71.3 & \\
\hline & - & - & + & $29 \cdot 3$ & \\
\hline & - & + & + & $42 \cdot 3$ & \\
\hline & + & - & - & $31 \cdot 2$ & 3 \\
\hline & + & + & - & 74.9 & \\
\hline & + & - & + & $30 \cdot 8$ & \\
\hline & + & + & + & $72 \cdot 6$ & \\
\hline $\mathrm{p} \Delta \mathrm{MycER}$ & - & - & - & 28.7 & 44 \\
\hline & - & + & - & $72 \cdot 1$ & \\
\hline & - & - & + & 28.9 & \\
\hline & - & + & + & $40 \cdot 5$ & \\
\hline & + & - & - & $30 \cdot 0$ & 35 \\
\hline & + & + & - & 77.4 & \\
\hline & + & - & + & 29.5 & \\
\hline & + & + & + & 50.2 & \\
\hline
\end{tabular}

Y1 cells were transiently transfected with pMycER, $\mathrm{p} \Delta \mathrm{MycER}$ and $\mathrm{pBabe}$ and then they were cell cycle arrested by serum starvation in SFM for $48 \mathrm{~h}$ as described in the Materials and Methods section. The main points in the time course of the experiments are indicated in the headings of the columns. Concentrations: $200 \mathrm{nM}$ 4-hydroxytamoxifen (4'OHT); $1 \mathrm{nM}$ FGF2; $1 \mathrm{nM}$ ACTH; $100 \mu \mathrm{M}$ BrdU. Incorporation of BrdU was assessed between 12 and $24 \mathrm{~h}$. Values of percent BrdU-labeled nuclei were pooled from 4 independent experiments (more than 4000 nuclei counted per condition) for MycER and pBabe and from 2 independent experiments (more than 2000 nuclei counted per condition) in the case of $\triangle$ MycER. Note the conditions in which cells are treated with 4' $\mathrm{OHT}$ (denoted by +in the 'Induction 4'OHT' column) to induce MycER migration to the nucleus, abolishing the ACTH inhibitory effect over FGF2 stimulation of $S$ phase entry. The column entitled 'ACTH inhibition' displays percent inhibition by ACTH of S phase entry stimulated by FGF2, calculated according to the following expression: \% inhibition=100 $-[((\mathrm{FGF} 2+\mathrm{ACTH}) / \mathrm{FGF2}) \times 100]$. Differences between values of percent BrdU-labeled nuclei were statistically analyzed by $\chi^{2}$ with one degree of freedom. In all cases, differences between FGF2-stimulated and untreated controls were statistically significant $(P<0.001)$, irrespective of the kind of transfection and $4{ }^{\prime} \mathrm{OHT}$ treatment. Differences between FGF2-stimulated and FGF2-stimulated+ACTH were statistically significant $(P<0.001)$ for both pBabe and p $\triangle$ MycER transfections, independent of 4 'OHT treatment. On the other hand, for pMycER transfection the difference between FGF2-stimulated and FGF2-stimulated+ACTH was statistically significant $(P<0.001)$ for $4^{\prime} \mathrm{OHT}$-untreated cells, but not for $4^{\prime} \mathrm{OHT}$-treated cells. $t=$ time.

over-expression of both c-Ki-ras mRNA and protein in Y1 adrenocortical cells, leading to constitutive high levels of c-Ki-Ras-GTP (Forti et al. 2002) and, consequently, partial deregulation of cell cycle control. Downstream of chronic c-Ki-Ras-GTP high levels, the PI3K/AKT pathway is kept constitutively active, suppressing the expression of the CDKinhibitor p27 kipl protein (Forti \& Armelin 2000,
Forti et al. 2002). Attenuation of the constitutive levels of c-Ki-Ras-GTP in $\mathrm{G}_{0} / \mathrm{G}_{1}$-arrested Y1 cells, by enforced expression of the dominant negative mutant HaRasN17, renders the PI3K/AKT pathway stringently dependent on mitogen activation (Forti et al. 2002).

In spite of the chronic high levels of c-Ki-RasGTP, Y1 cells retain tight regulation of the 
mitogenic pathway comprised of the following sequential events: (a) activation of the ERK1/2MAP kinases (Lotfi et al. 2000), (b) induction of the fos/jun families of proto-oncogenes (Kimura et al. 1993, Rocha et al. 2003), and (c) induction of the gene encoding the cyclin D1 protein (Schwindt et al. 2003). In addition, the induction of c-myc gene expression stressed in this article (Fig. 1 and supplementary data, Figs S1 and S2) is another essential event within this mitogenic pathway that is dependent on ERK1/2 activation (Fig. 1B). The stringent dependency of the ERK1/2 pathway on mitogens accounts for the remarkable cell cycle control displayed by Y1 cells upon serum step down and serum step up (Armelin et al. 1977, 1996, Lotfi \& Armelin 2001, Rocha et al. 2003).

\section{$c-M y c$ role in the diverging effects of FGF2 and ACTH on Y1 cell cycle control}

Here we demonstrate that the antagonistic effect of ACTH towards the FGF2 mitogenic effect narrows down to the regulation of c-Myc protein availability (Tables 2 and 3), without change in the steady state levels of Max and Mad proteins (supplementary data, Fig. S3). Both c-myc transcription induction and $\mathrm{c}-\mathrm{Myc}$ protein stabilization are dependent on ERK1/2 activation, as evidenced by inhibition of MEK1 with the inhibitor PD98059 (Fig. 1E). Furthermore, reduction in c-Ki-Ras-GTP levels by Ras-N17 over-expression abolishes the basal levels of the c-Myc protein found in $\mathrm{G}_{0} / \mathrm{G}_{1}$-arrested $\mathrm{Y} 1$ cells (Fig. $4 \mathrm{~B}$ and $\mathrm{C}$ ) in correlation with a sharp decrease in the basal levels of DNA synthesis (Fig. 4E and F). Our data implicate PI3K as the pathway downstream of c-Ki-Ras-GTP controlling c-Myc basal deregulated levels. Inhibition of PI3K with wortmannin causes a severe reduction in c-Myc basal levels regardless of the treatment to which Y1 cells were submitted (Fig. 1D). Thus, in Y1 cells, the c-myc gene expression, whose regulation is mainly exerted at gene transcription rates (Table 1 and supplementary data, Fig. S1) and protein stability levels (Table 2, Fig. 3 and supplementary data, Fig.S2), is under coordinated control by both the ERK1/2 and PI3K pathways.

ACTH promotes a cAMP/PKA-dependent rapid degradation of the c-Myc protein (Fig. 2A, $\mathrm{B}$ and $\mathrm{C}$, Fig. 5, Table 2), per se, a sufficient characteristic to qualify ACTH as a strong anti-mitogenic hormone. In addition, we function- ally demonstrate that sustained expression of the c-Myc protein eliminates the antagonistic effect of ACTH towards FGF2 mitogenic activity in $\mathrm{G}_{0} / \mathrm{G}_{1}$-arrested $\mathrm{Y} 1$ adrenocortical cells (Table 3 ).

Recognition of c-Myc protein by the ubiquitin proteolytic system (Salghetti et al. 2000) requires sequential phosphorylation of both Ser62 and Thr58 (Sears et al. 2000), whose regulation is complex. First, phosphorylation of Ser62 by ERK1/2 promotes protein stabilization, whereas subsequent phosphorylation of Thr58, catalyzed by GSK3, renders c-Myc recognizable by the ubiquitin system (Sears et al. 2000). Akt phosphorylates and inactivates GSK3, limiting c-Myc phosphorylation at Thr58 (Sears et al. 2000) and contributing to stabilization of the c-Myc protein. In Y1 cells, chronic high levels of Ki-Ras-GTP keep the PI3K $\rightarrow$ Akt pathway constitutively activated (Forti et al. 2002), favoring c-Myc protein stabilization. On the other hand, ACTH rapidly dephosphorylates/ deactivates Akt (Forti et al. 2002), that should release GSK3 activity to target c-Myc for degradation. Therefore, the pathway activated by ACTH in Y1 cells might comprise the following steps: ACTH receptor $\rightarrow \mathrm{cAMP} / \mathrm{PKA} \rightarrow \mathrm{Akt}$ deactivation $\rightarrow$ GSK3 activity release $\rightarrow$ c-Myc Thr58 phosphorylation. However, this ACTH pathway seems to be important only when Akt is maintained activated by constitutively high Ki-RasGTP levels, because the $\mathrm{Y} 1$ transfectant clones RasN17-1.5 and RasN17-3.1 with low Ki-RasGTP levels are relatively resistant to ACTH inhibition of c-Myc induction (Fig. 4B and C) and S phase entry (Fig. 4E and F).

Cyclin D1 has also been considered a substrate of GSK3 and, for that reason, is stabilized by activated Akt found in many human malignant tumors (Liang \& Slingerland 2003). But, in Y1 cells ACTH inactivates Akt without interfering with FGF2 induction of cyclin D1 (Fig. 2D).

Here we show co-expression of $\mathrm{c}-\mathrm{Myc}$, Mxi, Mad-1 and Mad-4 in Y1 adrenocortical cells. The canonical picture of the Myc/Max/Mad network involves the notion that the ratio between c-Myc and Mad levels controls the balance between cell proliferation and differentiation (Grandori et al. 2000). However, there are reports of co-expression of c-Myc and Mad proteins in the same cell nucleus (Yin et al. 2001). In thymus, at least one of the Mad proteins is expressed in each maturation stage and c-Myc co-expression remains important for both 
proliferation and survival of thymocytes (Rudolph et al. 2001, Chi et al. 2003). Co-expression of c-Myc and Mad is also observed during condrogenesis and bone deposition (Quéva et al. 1998). Thus, co-expression of c-Myc and Mad proteins in $\mathrm{Y} 1$ adrenocortical cells is not unique. We hypothesize that, in $\mathrm{Y} 1$ cells, c-Myc is a key component of the cell proliferation control system, whereas the constant expression of Mad proteins is important to maintain the differentiated and functional state of this cell line.

In conclusion, it has for long been accepted (Masui \& Garren 1971, Rae et al. 1980, Schimmer et al. 1986) that ACTH possesses anti-mitogenic effects exerted via the cAMP/PKA pathway, but its molecular mechanisms have remained essentially unknown. This report and our previous publications (Forti \& Armelin 2000, Lepique et al. 2000, Forti et al. 2002) demonstrate in Y1 adrenocortical cells that the ACTH receptor, via the cAMP/PKA pathway, elicits Akt deactivation leading to c-Myc protein destabilization (this paper) and upregulation of the CDK-inhibitor, p27 Kipl (Forti et al. 2002). In addition, we also report that sustained expression of $\mathrm{c}-\mathrm{Myc}$ is sufficient to override these anti-mitogenic mechanisms of ACTH, suggesting that control of c-Myc protein stability is the main focus of the antagonism between ACTH and mitogens such as FGF2.

\section{Acknowledgements}

This work was supported by grants from FAPESP (Fundação de Amparo a Pesquisa do Estado de São Paulo) and CNPq (Conselho Nacional de Desenvolvimento Científico e Tecnológico) to HA A. KMR was a postdoctoral fellow and A P L, M S M, G B E, T T S and G N M H were pre-doctoral fellows from FAPESP.

\section{References}

Armelin MC, Gambarini AG \& Armelin HA 1977 On the regulation of DNA synthesis in a line of adrenocortical tumor cells: effect of serum, adrenocorticotropin and pituitary factors. Fournal of Cell Physiology 93 1-9.

Armelin HA, Lotfi GFP \& Lepique AP 1996 Regulation of growth by ACTH in the Y-1 mouse adrenocortical cells. Endocrine Research 22 373-383.

Bradford MM 1976 A rapid method for the quantification of microgram quantities of protein utilizing the principle of protein-dye binding. Analytical Biochemistry 72 248-254.
Cai H, Szeberenyi J \& Cooper GM 1990 Effect of a dominant inhibitory Ha-ras mutation on mitogenic signal transduction in NIH 3T3 cells. Molecular Cell Biology 10 5314-5323.

Chi TH, Wan M, Lee PP, Akashi K, Metzger D, Chambon P, Wilson CB \& Crabtree GR 2003 Sequential roles of Brg, the ATPase subunit of BAF chromatin remodeling complexes, in thymocyte development. Immunity 19 169-182.

Feig LA \& Cooper GM 1988 Inhibition of NIH 3T3 cell proliferation by a mutant ras protein with preferential affinity for GDP. Molecular Cell Biology 8 3235-3243.

Forti FL \& Armelin HA 2000 ACTH inhibits Ras-dependent anti-apoptotic and mitogenic pathway in mouse Y1 adrenocortical cells. Endocrine Research 26 911-914.

Forti FL, Schwindt TT, Moraes MS, Eichler CB \& Armelin HA 2002 ACTH promotes $\mathrm{p} 27^{\mathrm{kip} 1}$ induction in mouse $\mathrm{Y} 1$ adrenocortical tumor cells dependent on both PKA activation and Akt/PKB inactivation. Biochemistry 41 10133-10140.

Grandori C, Cowley SM, James LP \& Eisenman RN 2000 The $\mathrm{Myc} / \mathrm{Max} / \mathrm{Mad}$ network and the transcriptional control of cell behavior. Annual Review of Cellular and Developmental Biology 16 653-699.

Kimura E \& Armelin HA 1988 Role of proto-oncogene c-Ki-ras amplification and overexpression in the malignancy of Y-1 adrenocortical tumor cells. Brazilian fournal of Medical and Biological Research 21 189-201.

Kimura E, Sonobe MH, Armelin MC \& Armelin HA 1993 Induction of FOS and JUN proteins by adrenocorticotropin and phorbol ester but not by 3',5'-cyclic adenosine monophosphate derivatives. Molecular Endocrinology 7 1463-1471.

Lepique AP, Forti FL, Moraes MS \& Armelin HA 2000 Signal transduction in G0/G1-arrested mouseY1 adrenocortical cells stimulated by ACTH and FGF2. Endocrine Research 26 825-832.

Liang J \& Slingerland JM 2003 Multiple roles of the PI3K/PKB(Akt) pathway in cell cycle progression. Cell Cycle 2 339-345.

Littlewood TD, Hancok DC, Danielian PS, Parker MG \& Evan GI 1995 A modified estrogen receptor ligand-binding domain as an improved switch for the regulation of heterologous proteins. Nucleic Acid Research 23 1686-1690.

Lotfi CFP \& Armelin HA 2001 cfos and cjun antisense oligonucleotides block mitogenesis triggered by fibroblast growth factor-2 and ACTH in mouse Y1 adrenocortical cells. Fournal of Endocrinology 168 381-389.

Lotfi CF, Todorovic Z, Armelin HA \& Schimmer BP 1997 Unmasking a growth-promoting effect of the adrenocorticotropic hormone in Y1 mouse adrenocortical tumor cells. Fournal of Biology Chemistry 272 29886-29891.

Lotfi CF, Costa ET, Schwindt TT \& Armelin HA 2000 ERK/MAP kinase in mitogenic interaction between ACTH and FGF2 in mouse Y1 adrenocortical tumor cells. Endocrine Research $\mathbf{2 6}$ 873-877.

Masui H \& Garren LD 1971 Inhibition of a replication in functional mouse adrenal tumor cells by ACTH mediated by cAMP. PNAS 68 3206-3211.

Olson MF, Frolczyk AJ, Gorman KB, Steinberg RA \& Schimmer BP 1993 Molecular basis for the 3',5'-cyclic adenosine monophosphate resistance of Kin mutant Y-1 adrenocortical tumor cells. Molecular Endocrinology 7 477-487.

Quéva C, Hurlin PJ, Foley KP \& Eisenman RN 1998 Sequential expression of the MAD family of transcriptional repressors during differentiation and development. Oncogene 16 967-977.

Rae PA, Zinman H, Ramachandran J \& Schimmer BP 1980 Responses of Y1 adrenocortical tumor cell to o-nitrophenyl sulfenyl ACTH. Molecular and Cellular Endocrinology 17 171-179.

Rocha KM, Forti FL, Lepique AP \& Armelin HA 2003 Deconstructing the molecular mechanisms of cell cycle control in a mouse adrenocortical cell line: roles of ACTH. Microscopy Research Technique 61 268-274. 
Rudolph B, Hueber AO \& Evan GI 2001 Expression of Madl in $\mathrm{T}$ cells leads to reduced thymic cellularity and impaired mitogen-induced proliferation. Oncogene $201164-1175$.

Salghetti SE, Muratani M, Wijnen H, Futcher B \& Tansey WP 2000 Functional overlap of sequences that activate transcription and signal ubiquitin-mediated proteolysis. PNAS $973118-3123$.

Schimmer BP 1981 The adrenocortical tumor cell line, Y-1. In Functionally Differentiated Cell Lines, pp 61-92. Ed. G Sato. New York: Alan R Liss, Inc.

Schimmer BP, Wong M, O'Brien D \& Schulz P 1986 Recovery of hormonal regulation in protein kinase defective adrenal cells through DNA-mediated gene transfer. Fournal of Cellular Physiology $12677-83$.

Schwab M, Alitalo K, Varmus H, Bishop J \& George D 1983 A cellular oncogene (c-Ki-ras) is amplified, overexpressed and located within karyotypic abnormalities in mouse adrenocortical tumor cells. Nature 303 497-501.

Schwindt TT, Forti FL, Juliano MA, Juliano L \& Armelin HA 2003 Arginine vasopressin inhibition of cyclin D1 gene expression blocks the cell cycle and cell proliferation in the mouse Y1 adrenocortical tumor cell line. Biochemistry 42 2116-2121.

Sears R, Nuckolls F, Haura E, Taya Y, Tamai K \& Nevins JR 2000 Multiple Ras-dependent phosphorylation pathways regulate Myc protein stability. Genes and Development 14 2501-2514.

Weidman ER \& Gill GN 1977 Differential effects of ACTH or 8 BrcAMP on growth and replication in a functional adrenal tumor cell line. Fournal of Cellular Physiology 90 91-103.

Yasumura Y, Buonassissi Y \& Sato G 1966 Clonal analysis of differentiated function in animal cell cultures. I. Possible correlated maintenance of differentiated function and the diploid karyotype. Cancer Research 26 529-535.

Yin X, Landay MF, Han W, Levitan ES, Watkins SC, Levenson RM, Farkas D \& Prockownik EV 2001 Dynamic in vivo interaction among Myc network members. Oncogene 20 4650-4664.

Received in final form 2 July 2004 Accepted 9 August 2004 